\title{
PENELITIAN \\ Perkembangan Masyarakat dan Agama Masa Depan
}

\author{
Oleh : M. Hajar Dewantoro
}

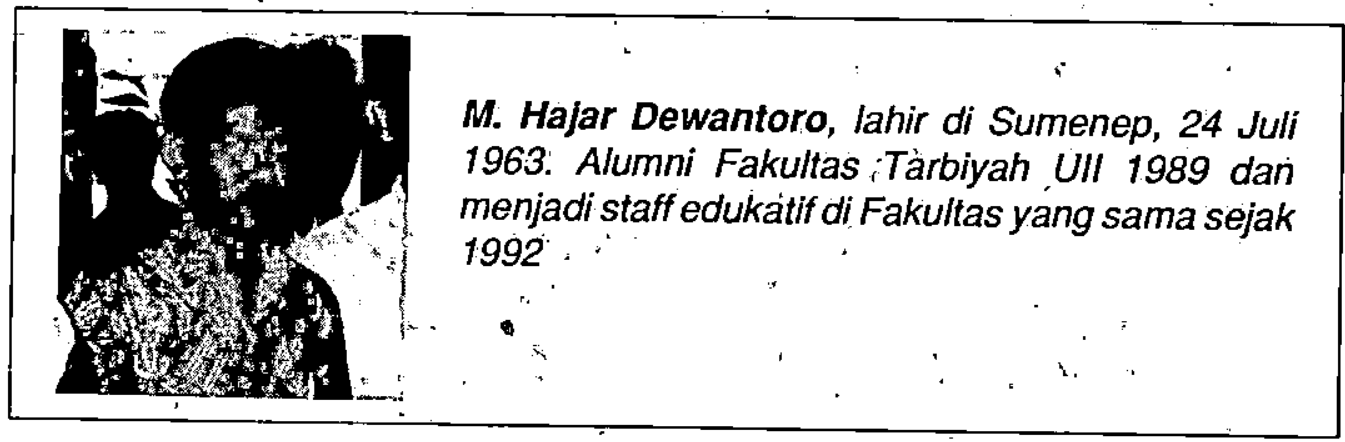

\section{Latar Belakang}

Secara tekstual teorisasi masyarakat mengalami perbedaan definisi disesuaikan dengan disiplin keilmuan mereka. ${ }^{1)}$ Konsepsi yang ditawarkan merupakan alternatif dari primes-primes tentang keberadaan" masyarakat. Primes-primes tersebut akan memunculkan tipologi yang. berkecenderungan pada suatu proses dálam mempertahankan ëksistensi masyarakat sebagai kesatuan darikomponen-komponen yang terdapat dalam manusia. Biasanya proses yang ditampilkan direduksi dari masyarakat satuke masyarakat lain. Realitas ini berbentuk evolusi dan revolusi2 ${ }^{2}$, yang dilengkapi simbolisme; ini semua merupakan bagian dari usaha lewat pengalaman dankecendenungan intelektual terhadapmasyarakat. Bilainidikategorikan fenomena, maka fenomena tersebut telah. mengangkat kecenderungan pemahaman intelektual masyarakat akan evolusi dan revolusi.
Adanya evolusi dan revolusi akan melahirkan transformasi dalam masyarakat. Namun demikian adanya transformasi masyarakat merupakan generalisasi dari beberapa konsep tentang masyarakat. Dengan demikian akan menghilangkan diskondsistensi yang ada, sehingga terbentuk hubungan yang logis antara asumsi-asumsi daŝar tentang kemasyarakatan. Kemasyarakatan dan. persepsi masyarakat tentang asumsi-asumsi tersebut. Oleh karena itu dapat dikatakan bahwa konsep-konsep yang telah ada dimunculkankembali dalam bentuk konteks baru yang, mencakup versi yang telah dimodifikasikan sesuai sistem dan tatanan suatu masyarakat. Namun demikian, konteks baru tersebut bukanlah suatu model atau tipe ideal menurut agama.

Adalah kurang obyektif dan naif sekali bila konteks tersebut dianalogikan sebagai hal yang fleksibel, lebih sederhana, logis dan murni, daripada membuat sesuatu 
diskripsi yang berasal dari pandangan orang-orang tertentu sepertikonsep-konsep agamawan, sosiolog, antropolog dan sebagainya. Tampaknya konteks di atas kurang nyata, namun suatu model atau tipe sebenamya merupakan hasil saringan dari beberapa kasus empiris yang asumsi dasamya diambil dari gejolak masyarakat pada suatui mașa, dan periode tertentu. Namun kenyataannya berbeda, kónteks hasil rekayasa intelektual manusia yang telah dimodifikasi mendapat tanggapan hangat dan konteks itu akan diaplikasikan terus sampai muncul versi baru yang sesuai dengan sistem tatanan masyarakat.

Untuk dapat menilai secara obyektif akan konteks yang berbentuk konsepsi tentang masyarakat pada era industri.ini, dibutuhkan beberapa pendekatan dengan menggunakan prasyarat (pra kondisi) bagi terjadinya revolusi. Ada tiga sudutpandang yang dapat dijadikan premis dan asumsi dalammengadakan pendekatan. ${ }^{3}$.Altematif ini dapat dijadikan persepsi akan adanya perubahan masyarakat yang mengarah pada perkembangannya. Namun bagaimana dengan agama itu sendiri tentang adanya perubahan tersebut.4) Agama sendiri tetap respek akan perubahan masyarakat selama nilai-nilai yang terkandung di dalamnya tetapmerupakannorma dan eksistensi suatu masyarakat.

Sebenarnya eksistensi yang terkandung dalam masyarakat merupakan eksistensi manusia, karena masyarakat merupakan kelompok manusia yang menginginkan kemajuan kelompoknya dengan mempertahankan eksistensinya sebagai nilai luhur (fitrah) asal. Konsepsi masyarakat sebenamya merupakan hasil dari cakrawala pemikiran ilmuwan yang didasarkan pada penelitian ilmiah, rasional dan argumentatif. Bila dilihat dari latar bekalang historis akan diketahui bahwa konsepsi tentang kemasyarakatan tumbuh dan berkembang di dunia Barat, subumya konsepsi tersebut dikarenakan sangat relevan dengan situasi dan kondisi masyarakat yang mulai meninggalkan agama.5) Agama dianggapnya momok, penghalang dan kurang relevan lagi bagi kehidupan. Oleh 'karenanya keberadaan agama tidak diakui lagi, bahkan lebih jauh perkembangan masyarakatmemuncak pada abad 20, dimana aliran-aliran baru mulai melepaskan diri dari individualisme abad 19.9

Munculnya masyarakat baru telah menumbuhkan kekecewaan yang dalam dan hasil yang tidak memuaskan bagi sistem tatanan sosial dan manusia sendiri, bahkan dapat dikatakan kemunculannya telah mengancam eksistensi manusia yang seluruh komponen tubuhnyaberisikạnnilainilai sebagai pengontrol dan pengendali gerakan tubuh. Perubahan transformatif kultur sosial banyak dialami dunia ketiga (dunia berkembang), dimana mayoritas pemeluk agamanya adalah Islam. Yang lebih memprihatinkan lagi, setiap mempertanyakan perubahan transformatif kultur sosial selalu mendapat tanggapan teoritis yang mendasari konsep perubahan sosial, tanpa melibatkan agama sebagai ruang lingkup luas dan mencakup nilainilai, norma dan sistem kemasyarakatan yang permanen. Bila hal ini dijadikan altematif, suatu sistem dan tatanan sosial yang konstan, makakeberadaan masyarakat akan lepas dari nilai-nilai sebagai eksistensi manusia. Jika demikian keberadaannya maka kesatuan másyarakatsudah tidak utuh. 
lagi dan perubahan transformatif masyarakatmerupakan rekayasa pemikiran manusia yang.tidak absolut.

\section{Pokok Masalah}

Munculnya tipe masyarakat baru akibat revolusi dan transformasi masyarakat telah memunculkan masalah:

1. Sejauhmana perubahan internal stuktur masyarakat sebagai akibat perubahan eksternal dalam mempengaruhi eksistensi manusia sehingga terjadi disorganisasi masyarakat.

2. Sejauhmana integrasi dan stabilitas mendapat prioritas dari anggota masyarakat dalam memelihara dan mempertahankan eksistensinya setelah mengalami disintegrasi dalam berbagai bidang kehidupan mereka.

3. Dampak apakah yang dialami agama dengan adanya disorganisasi dan disintegrasinya secara integral:

\section{Tujuan Penelitian}

- Penelitian ini bertujuan untuk:

1. Mengetahui perubahan intemal struktur masyarakat dan akibatnya bagi, eksistensi manusia sebagai modal dasar manusia dalam berkomunikasi dan. berintegrasi dengan masyarakat. :

2. Mengetahui terdapat tidaknya prioritas anggota masyarakat dalam memelihara danmempertahankan eksistensinya dari adanya disintegrasi dalam aset kehidupan mereka.

3. Mengetahui dampak yang dialami agama dan pengaruhnya terhadap tatanan kosmis masyarakat.

4. Mengetahui secara pasti permasalahan yang terjadi pada tatanan kosmis dan tatanan keduniawian dan mencari jalan keluar sebagai antisipasi terhadap revolusi dan transformasi masyarakat.

\section{Metodologi Penelitian}

Metode yang digunakan adalah analisa konsep, dimana metode ini mengandalkanketajaman analisis sekaligus menyajikan jalan keluar dari"stagnàsi teori" dalam ilmu-ilmu sosial.

Metóde ini mencoba melihat secara kritis terhadapteori-teori yang sangatumum (grand theories) guna menemukan generalisasi empiris dari konsep-konsep yang telah ditetapkan dan membuktikan kebenaran sebuah teori serta mengembangkan teori-teori yang telah ada guna menemukan seberapa jauh hubungan antara teori-teori yang ada dengan suatu gejala yang telah berlaku secara umum. Penelitian ini bertujuan membuat diskripsi yang lebih spesifik lagi akan keberadaan situasi sosial yang dilandaskan pada teoriteori yang telah ada. Penelitian ini menggunakan verifikasi terhadap beberapa teori untuk menemukan sesuatu kebenaran dan hasilnyà dàpat dikembangkan melalui teori juga sebagai indikasi dari kebanyakan prilaku yang umum dan relevan.

\section{Hasil Penelitian}

\section{Revolusi dan - Transformasi} Masyarakat

Beberápa kesulitan di atas. itu bisa dengan mudah diselesaikan bila mengakui dan menyadari bahwa keberadaan masyarakat bisa berubah sesuai dengan tipe ideal yang diinginkan masyarakat yaitu yang berisi keserasian dan keseimbangan dalam tatanan dan sistem masyarakatnya. Bila kenyataan ini terjadi, secara langsung maupun tidak langsung telah 
menghancurkan'seluruh gagasan, tentang: transformasi masyarakat pada era industrialisasi yang tidak didasarkan pada nilai-nilai kemanusiaan dan kodratnya yang ajek. Untuk mengetahui secara pasti status masyarakat dari masa ke masa, mengkaji kembali kebenaran masyarakat perlu untuk memperoleh kebenaran. Dalam hal ini masalah ilmu memperoleh prioritas tersendiri sebagai sarana mencari keautentikan masalah. Biasanya ilmu yang digunakan dapat dikategorikan sebagai ilmu obyektif atau sains, sedangkan ilmu subyektif merupakan pembimbing dan pengontrol bagi ilmu obyektif.?

Kalau ilmu subyektif memberikan landasan yang konkrit tentangmasalah yang terjadi dalam lingkungan masyarakat, dengan argumentasi aktual dan penjelasan yang gamblang, sedangkan ilmu obyektif yang merupakan hasil rekayasa pemikiran manusia masih memerlukan sandaran dan pijakan untuk menerangkan dan menguraikan suatu masalah, agar apa yang dịterangkan dan diuraikan selalu sesuai dan argumentatif serta sesuai dengan eksistensi manusia. Realitas ini adalah wajar karena hal tersebut masih memerlukan ilmu subyektif (naqal) untuk menuntunnya.

-Konsepsi perubahan transformatif sosial telah mempengaruhi jalan dan kehidupan kemasyarakatan sekarang, akibatnya kehadiran perubahan sosial memunculkan dua problema; ipertama. menerima kehadirannya dan mengikuti aspek-aspek yang terkandung di dalamnya; kedua, menolak suatu perubahan transformatif kultur sosial. Penolakan mereka wajar, jika konsepsi yang ditawarkan tidak berhasil meluruskan dan meluaskan jangkauan penerapannya dalam stratifikasi sosial atau konsepsi yang diajukan tidak mencerminkan konsepkonsep Islami bagi segala aktivitas manusia dan sosial. Akibatnya, konsepsi tersebut tidâk akan mampu memuaskan generasi muda sebagai tonggak masyarakat dan dapat menyelamatkan mereka dari serangan keraguan yang melumpuhkan tujuan perubahañ transformatif yang mencerminkan tatanan sosial yang terpecahpecah.

- Kelonggaran dunia Barat dengancara berpikir bebas telah membantu Marxis dan Weber untuk menaklukan pikiran manusia dengan konsep-konsep baru sebagai hasil penemuan mereka dari ketajaman berpikir yang didasarkan pada metode ilmiah. Konsepsi yang ditawarkan Marxis dan Weber secara tekstual harus diakui kebenarannya, namun secara kontekstual validitas dan akurasi konsepsinya serta aplikasinya kurang memenuhi porsi yang sebenamya. Adalahnaifbila konsepsi yang diajukan Marxisdan Weberdipandang lepas dari dogma suatu kemantapan konseptual dari suatu cita-cita.

Suatu proses perubahan yang mengacu pada perubahan transformatif sosial paling tidak mencakup tiga prinsip dasar yaitu individu, masyarakat dan komunitas dari individu itu sendiri. Ketiga komponen di atas memiliki kandungan realitas baik material maupun spiritual, kandungannya memiliki peranan yang menentukan sifat manusia dan nasibnya. Oleh karenanya suatu tekstual harus diakui kebenarannya bila hal tersebut tidak bertentangan dan relevan dengan realitas hidup yang berintikan keserasian dan keseimbangan. 


\section{Pola-pola Perubahan}

Timbulnya revolusi pada abad 18 merupakan hasil interpretasi pengalaman historis dari berbagai bangsa, kemunculannyamendapat tanggapanserius dari kalangan ilmuwan ${ }^{87}$ sebagai hasil dari analisa. Wama revolusi pada abad tersebut telah memberikan alternatif terhadap revolusi berikutnya dan akan mempengaruhi keadaan sosial beserta tatanannya. Ulasan dan argumentasi yang lebih konkritmengenai revolusi terjadi pada abad 20, yang dipelopori beberapa tokoh penting di zamannya." Konsepsi mereka banyak menyimpang dari citra revolusi sebagai suatu perubahan sosial yang terdiri dari tatanan nilai yang komprehensif. Akibatnya,- pertentangan pendapat pada bangsa Eropa sebagai pembawa revolusi semakin mencolok, efek yang diterima adalah menerima atau menolak revolusi. Realitas ini dapat dilihat dari batasanbatasan dari definisi yang dikemukakan mereka. ${ }^{10)}$

Kạlau revolusi diartikan membawa dampak negatif seperti munculnya stratifikasi sosial dan klasifikasinya, itu tidak benar. Karena stratifikasi dan klasifikasi sosial memang sudah ada sejak manusia ada. Bila dilihat dari stratifikasi sosial sebenamya dapat digolongkan pada berbagai jenis, namun yang muncul dan paling menonjol adalah dua stratifikasili) dengan ciri-ciri tertentu. ${ }^{12)}$ Terdapatnya stratifikasi sosial berdampak negatif terhadap nilai-nilai sosial ${ }^{13)}$ dan hal tersebut telah mengkristal bahkan menjadi etos tersendiri dalam melakukan partnership antara sesamanya. Kenyataan ini memang pahit, namun demikianlah strata sosial yang ada saat ini.
Kondisi sosial yang demikian itu memang memprihatinkan, tetapi bila dikaji dan ditelaah kembali akan diketahui bahwa keberadaan masyarakat dengan stratifikasinya bukan hanya suatu striktur sosial yang terkoordinir, melainkan suatu proses yang kompleks baik dari sisi nilainilai, hubungan maupun tujuannya. Dari sana akan diketahui bahwa tujuan masyarakat relatif stabil pada suatu momen tersendiri dân kondisi tertentu. Bila kondisi di atas dijadikan suatu altematif perubahan sosial, maka jawabannya adalah_benar, karena dalam dirimasyarakat selalu memuat perubahan yang lambat namun bersifat kumulatif. Perubahan yang terjadi dapat berproses cepat dan kondisi demikian dianggapnya mengganggu keberadaan struktur sosial yang telah permanen. Perubahan yang didapat berbentuk komponen-komponen yang ada dalam masyarakat, baik dari segi hubungan antara sesama, nilai-nilai yang terkandung dalam masyarakat maupun dảri segi tujuannya. Transfer komponen-komponen baru sebenamya merupakan suatu proses yang berkesinambungan mengikuti masa dan kehidupan manusia. Adalah mustahil, bila keberadaan masyarakat tidak mengakui suatu perubahan yang ditimbulkan masa dan manusia itu sendiri sebagai gambaran obyektif tentang pertalian manusia yang berada dalam strata sosial dengan masyarakat sangat erat, itu disebabkan manusia merupakan bagian dari unsur komponen masyarakat dan masyarakat merupakan satuan komponen. Jika dalam stratifikasi sosial mengalami perubahan ini tidak lepas dari perubahan sosio kultural dan bahkan banyak dipengaruhi sosio budaya masyarakat. Sosio budaya 
masyarakat ini yang pertama mengalami perubahan transformatif karena massa juga ikut menentukan.

Lebih spesifik lagi digambarkan tentang keberadaan masyarakat pra industri dan masyarakat industri, dimana masyarakat sering mengalami perubahan secara.struktural, masalah ini memiliki relevansi yang fleksibel baik terhadap stratifikasi sosial maupun esenisi struktur sosio kultural masyarakat. Untuk mengantisipasi problema di atas dan menjadikan filter bagi struktur masyarakat yang komprehensif haruslah diusahakan suatu pemahaman akan suatu perubahan yang terjadi. Dengan kedalaman pemahamanterscbut keberadaan stratifikasi sosial tidak akan semakin keruh, dan bila dilema ini: dibiarkan mencuat tidaklah mustahil bila perubahan transformatif akan memiliki peluang besar dalam mengembangkan sayapnya untuk merubah nilai-nilai yang terdapat dalam struktursosio kultural masyarakat.

Melihat realitas ini Durkeim menggunakan istilah anomi ${ }^{15)}$ sebagai proses disorganisasi sosial. Dampaknegatif dari masalah tersebut, masyarakat mengalami disintegrasi dalam berbagai bidang kehidupan mereka dan hal tersebut mengharuskan mercka mencari jalan keluar sebagai alternatif baru menghadapi perubahan. Memang, semua masyarakat mengalami perubahan secara menycluruh menurut porsi mercka masing-masing bersama arus pemahaman mercka akan perubahan transformatif. Ruang lingkup perubahan transformatif adalah perubahan internal struktur masyarakat, sedangkan perubahan ekstemal yang terjadi dalam masyarakat merupakan interpretasi dari perubahan internal. Secara struktural ini mengancam eksistensi suatu masyarakat sebagai kumpulan nilai-nilai dan norma.

Kalau stratifikasi sosial semakin hari semakin menyurut, maka muncul penggantinya yaitu tipe-tipe masyarakat ${ }^{16}$ sebagai interpretasi baru dari adanya perubahan masyarakat. Jika masyarakat merupakan kesatuan komponen yang berperan aktif dalam mengembangkan atau menghambat kelangsungan suatu masyarakat, maka di dalamnya mencakup integrasi, keterpaduan dan stabilitas yang harus dilestarikan sampai batas minimum sekalipun. Ini dimungkinkan untuk mempertahankan eksistensi diri manusia dari bermacam-macam masyarakatmenurut pengalaman historis. Namun yang menjadi problema adalah sejauhmana integrasi dan stabilitas mendapat prioritas dari anggota masyarakat dalam memelihara dan mempertahankannya.

\section{Kondisi Masyarakat dalam Perubahan}

Munculnya tipe-tipe masyarakat sebagai interpretasi dari adanya stratifikasi masyarakat yang mulai usang karena pengaruh perjalanan sejarah, maka mengusahakan kembali suatu tipe yang ideal dan konsisten terhadap polaperubahan adalah citra revolusi. Namun demikian, fokus sentral dari suatu usaha di atas adalah mengembalikan nilai-nilai tatanan masyarakat secara struktural agar keberadaannnya selalu terjaga. Aspek yang sangat penting dari karakteristik struktural di atas ialah semakin meningkatnya keterlepasan dari berbagai tatanan nilai yang ada dalam masyarakat. Hambatan lain dari perubahan revolusioner yang bersifat 
transformatif bagi masyarakat modem terlihat dari ragamnya gerakan protes sosial yang berkisar pada gambaran revolusioner untukmelebarkan sayapnya dalam merekrut partisipasi masyarakat untuk merubah dan memperbaharui kandungan kebudayaan dan tatanan sosialnya dengan mencoba memecahkan sejumlah masalah penting yang diakibatkan era industrialisasi secara umum. Langkah ini merupakan tujuan utama dalam mengeksploitasi tipe masyarakat baru. Tujuan yang dijabarkan bertopang pada pengejawantahan,dimensi karismatik sebagai tatanan' sosio kultural modem.

Namun, dengan munculnya gerakan protes sosial, perkembangan dan pertumbuhan tipe masyarakat baru merupakan akses baru untuk menemukan keabsahan akan premis-premis revolusioner yang membawa bendera transformatif sebagai fokus utama untuk mengetahui 'proses dalam sistem sósial yäng baru saja muncul baiksecara parsial maupunmondial. Negara yang menempati posisi sentral dan berfungsi sebagai perwakilan distributif dan pengaturan harus memiliki akses terbuka bagi segala kelompok dalam memperjuangkan kepentingan mereka. Sejalan dengan itu negara harus mampu menjawab berbagai tuntutan yang luas dengan disertai desakan yang mendorong jiwa mereka dalam memperoleh kesejahteraan dan keseimbangan hidup dalam tatanan sosial baru.

Dengan adanya problema sosial di atas, telah memberikan gambaran yang jelas mengenai perkembangan masyarakatsecara kompleks; munculnya simbol-simbol dan gerakan revolusioner semakin nyata bahwa kekuatan alamiah masyarakatpasca industri menyerétmasyarakat kembali bergelut pada era industri sekarang yang penuh dengan simbol dan premis serta asumsi-asumsi. Bila munculnya protes dijadikan proses dalam menjelaskan perkembangan masyarakat, itu hanya analogi kosong belaka, karena dalam masyarakat modem simbol, premis dan asumsi-asumsi merupakan citra dari revolusioner.

Jika ditinjau kembali adanya perkembangan masyarakat yang melalui proses, maka proses yang dilontarkan mereka kurang argumientatif karena terdapat sejumlah kelemahan; pertama, tertutupnya kelembagaan negara dan membatasi akses ke dalam, merupakan kelemahan yang nyata. Akibatnya setiap ada perubahan dalam stratifikasi sosial dianalogikan sebagai perubahan di bidang politik. Analogi di atas sebenarnya merupakan primes-primes orisinil masyarakat modern yang keterkaitannya dengan perubahan masyarakat sudah tidak relevan lagi. Kelemahan yang kedua ialah di balik transformasi revolusioner telah menimbulkan sejumlah konflik dan kontradiksi yang berkaitan dengan industrialisasi dan perubahan struktural masyarakat, ini terlihat dalam pola-pola stratifikasi sosial yang mengalami perubahan, baik dalam sektor ekonomi maupun tatanan sosialnya." Partisipasi sebagai jalur komunikasi masyarakat mulai diganti dengan persepsi dan asumsi-asumsi lewat teori-teori saja Q.S. 61:2.

Bila realitas ini tidak cepat diantisipasi, kekecewaan dan hasil yang kurang memuaskan dari suatu perubahan akan menghancurkan tatanan struktur masyarakat. Persepsi dan asumsi-asumsi mereka merupakan percobaan untuk 
menjelaskan secara teoritís tentang ' mekanisme dan faktor-faktor perubahan sosial, dan itupun tidak didukung dasar ilmiah - yang cukup menjamin dimungkinkannya bagi setiap masyarakat di dunia baik secara operasional maupun non operasional. Ketidakrelevanan perubahan hampir mencakup semua aspek struktur masyarakat dalam hal itu akan memiliki efek-efeksampingantertentu yang tidak diinginkan masyarakat. Semakin jelas efek yang diterima masyarakat adalah dari arus penubahan adalah hilangnya identitas manusia dan masyarakat sebagai kumpulan dari beberapa komponen. Kenyataan ini sekarang mulai disadari oleh negara-negara berkembang.

Para revolusioner atas perubahan masyarakat cenderung menekankan bahwa dengan terjadinya perubahan tränsformatif akan memperbaiki hidup menuju kesejahteraan dan keseimbangan antar interaksi masyarakat, dalil tersebut,di atas merupakan produk-produk revolusi yang memaksa masyarakat ' untuk memanfaatkannya demi kebaikan dan kesejahteraanmasyarakat. Sedangkan nilainilai yang terkandung dalam masyarakat tidak termasuk salah satu aspek proses revolusi. Masalah inilah merupakan kekeliruan paling menonjol bagi mereka yang berakibat pada proses berpikir dan bahkan terhadap 'proses kehidupan masyarakat.

Terjadinya perubahan struktural masyarakat menciptakan pengaruh paling mendalam bagi proses berpikirmasyarakat, selain itu efek yang dialami masyarakat di terangkan Alain Touraine, Samuel P, Huntington dan Barington Moore. ${ }^{16)}$ Efek yang diterangkan, Alain Touraine dkk merupakan interpretasi dari proses berpikir manusia. Oleh karenanya dalam berbagai teori adanya perubahari masyarakat sedikit mempengaruhi tatanan struktur dan cara berpikir masyarakat dan hal itu akan membawa efek-efek sampingan bagi keberadaan masyarakat yang tidak lepas dari nilai-nilai dan norma.

\section{Agama dalam Perubahan Masyarakat}

Nilai-nilai yang terdapat dalam diri manusia merupakan mediator norma Q.S. 30:30, sedangkan norma dan nilai-nilai distatiragama. Agama inilah yang berfungsi memibimbing, mengarahkan dan mengembangkan eksistensi manusia sebagai salah satu aspek masyarakat. Oleh karenanya bila berbicara masalah masyarakat maka keterlibatan manusia secara integral sudah tentu, begitu pula agama. Adalah mustahil bila berbicara masalah perubahan masyarakat tidak melibatkan agama yang memiliki multi fungsi terhadap masyarakat dan perubahannya. Dan bila fungsi transformasi agama dianalogikan sebagai konsepsi teoritis mengenai perubahan, lepas dari agama adalàh salah, karena perubahan yang terjadi meskipun reproduksi kémbali nilainilai manusia yang disebut Islam (fitrah). Reproduksi ini dapat diimplementasikan sebagai pembaharuan nilai-nilai yang terkandung dalam diri manusia sebagai adaptasi manusia terhadap masa bersama situasi dan kondisinya.

Menganalisa kembali tentang implikasi kelembagaan sosial masyarakat yang didasarkan pada orientasi kebudayaan yang berbeda-beda akan menghasilkan konsepsi yang berlainan pula tentang 
tatanan sosial masyarakat, hal ini juga melibatkan persepsi mengenai tinggi rendahnya tingkat komitmen masyarakat terhadap tatanan sosial dan budaya dan tatanan kosmis. Ini berarti bahwa tatanan transendental dan tatanan keduniawian diperlukan untuk menciptakan suatu tatanan sosial masyarakat baru sebagai hasil dari suatu perubahan transformatif. Disebabkan tiadanya persepsi yang seragam antara tatanan kosmis dan tatanan keduniawian baik di dunia Barat maupun di dunia Timur telah menimbulkan ketegangan dalam menerima persepsi tersebut, akibatnya bermunculan asumsi-asumsi yang didasarkan pada suatu tatanan masyarakat setempat yang berorientasi pada artikulator solidaritas dari berbagai kolektivitas. Situasi ini akan melahirkan sumber-sumber bebas yang relatif tinggi dalam masyarakat, implementasinya keberadaan masyarakat kurang berkembang sesuai orientasi dan citra revolusi transformatif. Realitas ini tidak didasarkan pada lingkungan ekologis yang heterogen dan persepsi yang seragam, dampak yang dirasakan akan melahirkan diferensiasi strukturtanpamendorong nilainilai scbagai eksistensi manusia.

Adalah suatu kemungkinan untuk menyalurkan dan mempertalikan kembali antara sumber-sumber bebas yang dihasilkan oleh konsepsi dengan kondisi struktural masyarakat yang memprihatinkan guna mengarahkannya pada pembentukan tipe masyarakat bari yang memiliki hubungan erat antara tatanan kosmis dan tatanan keduniawian. Memang, pembentukannya lebih problematis dari yang diperkirakan oleh asumsi-asumsi dasar yang dijadikan persepsi masyarakat. Namun demikian, bukan tidak mungkin untuk mempersatukan kembali atribut-atribut yang melekat pada masyarakat dan. simbolis-simbolisnya untuk menemukan nilai-nilai kemanusiaan.

Sebagai contoh; lihat kembali perjalanan umat manusia pada masa pertumbuhannya dan perkembangannya, dimana agama sebagai tatanan kosmis banyak membantu tatanan keduniawian. Hasilnya cukup mengagumkan dunia dan secara keseluruhan dapat dikatakan bahwa tipe masyarakat baru mulai muncul dan memberikan cerminan kepada dunia luar. Hal ini dikarenakan dapat ditemukan kriteria obyektif yang berlaku untuk menilai peristiwa-peristiwa dalam bidang sosial yang kesemuanyamerupakan implementasi dari agama melalui tatanan kosmis yang ada. Keberhasilan masyarakat pada waktu itu mendorong orang-orang dari luar untuk mengetahui konsepsi yang diterapkan, namunusaha untuk mengetahui hal tersebut digunakan kriteria yang mudah dimengerti, namun secara kualitatif kurang memadai, sehingga observasi mereka akan masyarakat baru tidak disesuaikan dengan tatanan kosmis melainkan hanya didasarkan pada landasan ilmiah saja tanpa melibatkan agama. Hasil dari suatu observasi ilmiah terscbut memunculkan penilaian dinamika sosial, dalam bidang kemasyarakatan keagamaan yang. konsisten terbatas dan kurang jelas.

Akibatnya, persepsi dan asumsiasumsi dasar yang terbentuk dalam konsep mulai dianut masyarakat dunia (pada era industrialisasi) yang mencerminkan terbentuknya tipe-tipe masyarakatbaru dan kenyataan tersebut telah memunculkan konflik-konflik sosial yang sangat memprihatinkan. Berkenaan, dengan 
masalah ini Webermengakui namun secara implementatif Weber : tidak mengaplikasikan hal tersebut dalam konsepsinya secara konsisten. Akibatnya, adanya masyarakat baru sebagai inovasi dari masyarakat lama merupakan hasil persepsi dan asumsi-asumsi yang kurang jelas dan tidak saling berhubungan dengan tatanan kosmis masyarakat.

Adalah suatu kesalahan besar bila tatanan kosmis yang tercakup dalam nilainilai agama merupakan penghambat dan penghalang bagi kemajuan dan perkembangan suatu masyarakat, karena agama sendiri membenarkan perkembangan nilai-nilai masyarakat yang merupakan ciri khusus dari suatu kelompok masyarakat. Pandangan. ini didasarkan kepada kurang relevannya aturan agama memainkan peran aktifnya terhadap golongan masyarakat, dan kesalahan pandangan ini terlihat dari persepsi dan asumsi-asumsi mereka yang ingin melepaskan diri dari agama dalam setiap kajian ilmiahnya.

Kenyataan di atas dapat dilihat dari pandangan orientalis dan sekularis, ${ }^{17}$ ) namun tidak demikian dengan pandangan Mujaddid Islam abad 20 (Syekh Muhammad Abduh) ${ }^{18)}$ dan Ibnu Rusyd. Tetapi pandangan Ibnu Rusyd oleh bangsa Eropa dan Barat diambil secara teoritis empiris dan melepaskan agama dari segala yang berhubungan dengan empiris.

Menghidupkan kembali aturan agama dalam segala aset kehidupan akan terasa sulit, ini dikarenakan masyarakat baru dengan tatanankeduniawiannya sudah merasa terarah dan mendatangkan kesejahteraan lahir. Kenyataan ini juga dialami Prof. Paul Ehrenfest walaupun beliau dalam segala penyelidikannya memerlukan agama guna memperoleh kebenaran hakiki dalam penyelidikannya. Dan agama yang dapat menuntunperjalanan hidup manusia diterangkan dalam AlQur'an surat 3:19, 48:28, 51:9.

\section{Kesimpulan}

Beberapa kecenderungan masyarakat merupakan gejala dari kategorial masyarakat yang memunculkan tipologi sebagai interprestasi dari suatu masyarakat yang mengalami transformasi, diantaranya:

1. Muncul tipe masyarakat ban telah menghancurkan konsep tatanan masyarakat dan mendatangkan konflikkonflik yang periu diantisipasi.

2. Konsepsi tentang masyarakat baru berisikan asumsi-asumsi dasar dan persepsi simbolis sebagai lambangnya. Akibatnyakekecewaan kegelisahan dan ketidakpuasan masyarakat akan sistem tatanan masyarakat baru merupakan indikator utama.

3. Adanya tipe masyarakat baru telah menghilangkan eksistensi manusia. Ini terlihat dari hilangnya kodrat mereka dan sebagai gantinya adalah kepalsuan diri dalam setiap menjalani aset kehidupan.

4. Bila agama merupakan pranata, nilainilai dan norma yang muncul dari eksistensi manusia akan terkena imbasannya, hal ini adalah logis karena eksistensi manusia menjadi motor dan mediator utama dalam mengenal, memahami dan mengaktualisasikan pranata, nilai-nilai dan norma dalam kehidupan nyata. 


\section{Catatan Kaki}

1.Linton mendefinjsikan masyarakat adalah setiap kelompok manusia, yang telah cukup lama hidup dan bekerja sama (The Study of Man, New York, London, D.A. Mac Iver, masyarakal adalah satu sistem daripada cara kerja dan prosedur, daripada otoritas dan saling bantu membantu yang meliputi kelompok-kelompok dan pembagian sosial-sosial lain, sistem dari pengawasan tingkah laku manusia dan,kebebasan. Sistem yang komplek yang selalu berubah atau' jaringan-jaringan atau relasi sosial. (Society, an Introduction Analysis, New York, Rinehart and Company, Inc. 1957).

2. Evolusi dan revolusi yang dimaksud menupakan fenomena yang mempengaruhi gambaran diri (self-image) masyarakat-masyarakat modem dan berbentuk tamsil dan simbolisme sebagai ciri mereka.

3. Pendekatan yang dipergunakan dilihat dari tiga sudut pandang. yaitu:

- Theda Skocpol, mengatakan bahwa upaya untuk mengumpulkan teori-teori psikologi yang mencoba menjelaskan revolusi berkenaan dengan motivasi sebagai penggerak.

- Yang menelaah krisis intemal wars ditujukan pada identifikasi kondisi struktural yang menunjukkan kontradiksi yang inherén.

- Menelaah prakondisi revolusi yang bersangkut paut dengan identifikasi kondisi dalam lingkungan politik, budaya dan ekonómi.

4. Islam sebagai risalah telah meletakan batu pertama bagi pembentukan masyarakal yang stabil dan adil. masyarakat berseragam, berdasarkan hidup dan memberi hidup. Dinaksud yaitu dengan menghidupkan dhamirmasing-masing pribadi anggota masyarakat, dengan membangkitkan kesadaran akan kedudukarnya sebagai hamba Allah, dan kedudukan dirinya sebagai anggota yang bertanggung jawab torhadap kesejahteraan bersama (menumbuhkan daya disiplin dari dalam). (M. Natsir, Fighud Da'wah, Ramadhani, Solo, 1989, hal. 70).

5. Perkembangan masyarakat Eropa dan Barat karena pengaruh pemikiran rasionalnya Ibnu Rusyd. Sedangkan Islam tidak mengenal kebenaran ganda seperti di Eropa, tetapi kebenaran wahyu (agama) sejalan dan berkesesuaian dengan kebenaran akal, sehingga apabila umal Islam meninggalkan agama dengan dalih apapun merupakan kemunduran bagi mereka (Drs. Muhaimin. Problematika Agama dalam Kehidupan Manusia, Kalam Mulia, Jakarta, 1989, hal. 12).

6. Menurut Soepomo, pada abad itu timbul suatu kesadaran sosial yang baru yang mengakibatkan terjadinya perubahan-perubahan sosial. Pada waktu itu timbul aliran sosiologis sebagai lawan aliran dogmatis skolastik. (Prof. Dr. Soerjono Soekamto, SH, MA, Pribadi dan Masyarakat, Alumni, Bandung, 1983, hal. 149).

7. Dmu subyektif dapat dijadikan sarana untuk membuktikan kebenaran prinsip dasar yang dipakai untuk membangun sains, seperti: empirisme, rasionalisme, relativisme dan obyektifisme. (Dr. Ir. Hidayal Nataatmadja, Krisis Global Ilmu Pengetahuan dan Penyembuhannya, Iqra, Bandung, 1982, hal. 9).

8. Tanggapan mereka dengan mengulas kembali konsepsi revolusi adalah Emil Lederer, Gustav Landauer, Theodore Geiger dan Eugene Rosentock-Huessy.

9. Tokoh-tokoh revolusi pada abad 18 adalah. Tocqueville, Lorenz von Stein, dan Karl Marx, (S.N. Eisentadt, Op.Cit, hal. 4).

10. Gambaran revolusi yang meliputi unsur-unsur perubahan diskontinuitas dan pembaharuan menyeluruh dikemukakan:

- Carl Friedrich, mengatakan bahwa revolusi yang ditulis Euge Rosentock menyirarkan tentang sesuatu yang baru dengan bahasa yang kabur, lógika yang lain, revolusi dari seluruh nilai-nilai....... maka revolusi politik dapat dinumuskan sebagai penjugkir-balikan tatanan kekuasaan politik.

- Eugene Kamenka, menulis revolusi sebagai perubahan yang mendadak dan tajam dalam siklus kekuasaan sosial. Ia tercemin dalam perubahan radikal terhadap proses pemerintahan dan sekaligus perubahan radikal dalam konsepsi tatanian sosialnya. (Ibid, hal. 4-5).

11. Dua kelompok stratifikasi yang merionjol adalah:

-Kelompok priner disebut face to face groupyailukelompok yang anggotanya saling mengadakan interaksi sosial.

- Kelompok sekunder kebalikan dari kelompok di atas. (Dr. W.A. Gerungan, Psikologi Sosial, PT. Eresco, Bandung. 1988, hal. 85-86).

12. Sedangkan ciri-ciri yang ditampilkan:

- Terdapatnya motif yang sama antara individu dajam berinteraksi dan memiliki tujuan yang sama pula.

- Terdapatnya reaksi individu sesuai kecakapan masingmasing dalam mengadakan interaksi.

- Pembentukan dan penegasan struktur kelompok yang jelas yang terdiri atas peranan-peranán dan kedudukan hierarkis.

- Terjadinya penegasan dan peneguhan nomma-norma sebagai pedoman tingkah laku mereka yang. mengatur interaksi dan kegiatan mereka. (Ibid, hal. 88-89).

13. Nilai-nilai sosial yang méngkristal dalam pola berpikir dan berkelakuan kurang manusiawi. Karena pola berpikir mereka hanya dikendalikan oleh kekuatan batin saja (egoisme). Sedangkan masyarakat pada umuninya tersusun dảr beberapa strata dan hal banyak menguntungkan kelas elit dan merugikan kelas bawah. (Drs. D. Hendropuspito, O, C, Sosiolog Agama, BPK, Gunung Mulia, Yogyakanta, 1991, hal. 56-57).

14. Penggunaan istilah anomi oleh Durkhein dimaksudkan untuk menunjukkan bahwa keadaan disorganisasi sosial dimana berbagai bentuk sosial dan kultur yang telah mapan ambruk. (Thomas F.O'dea, Sosiologi Agama, Rajawali Press, Jakarta, 1990, hal. 108). 
15. Yang dimaksud tipe-tipe masyarakat, adalah teribentuk dus tipe yang saling kuat, yaitu:

- Tipe pertams adalah masyarakat dimans nilai-nilai yang sakral kuat seksli.

- Tipe kedua adalah gabungan antara masyarakat yang nilai-nilai sakrainya kuat dan nilai-nilai sekülerysng sangat beipengaruh:

- Tipe ketiga adalah tipe masyarakat yang nilai-nilai sekulernya sangat kuat dan berpengaruh bagi masyarakat dalam struktumya. (Elizabeth K. Notingham, Agama dan Masyarakat (Suatu Pengantar Sosiologi Agama, Rajawali Pres, Jakarta, 1990, hal. 50).

16. Efek dari terjadinya perubahan banyak menimbulkan konflik-konflik sosial, yaitu:

- Unsur yang berbeda-beda dari kelas pekerja terpilahpilah.

- Kedua, kelas pekerja dan kaum intelektual makin bertambah jauh atau timbul kesenjangan.

-Ketiga, mendorong perkembangan perselisihankelompok bertipe baru yang berbeda pola dan benluknya. (S.N. Einsentad, Op, Cit, hal. 393).

17. Pandangankaum orientalis bahwa pembebasan diri deri agarna menyebabtan bangsa Eropa dan bangsabanges Barat berhasil mencapaikemajuan di bidang industri, teknologi, produksi dan ekonomi serta integral (Drs. Muhaimin, Op, Cit, hal 11).

18. Pemyataan di atas disanggah Syekh Muhammad Abduh dengan mengatakan bahwa: umat Kristen maju karena meninggalkan agamanya, umat Islam mundur juga karena meninggalkan ajaran agama Islam (bid, hal. I1).

\section{Daftar Kepustakaan}

Elizabeth K. Nottingham, Agama dan Masyarakat (SuatuPengantar Sosiologi Agama), Rajawali Press, Jakarta, 1990. Einsentadt, Revolusi dan Transformasi Masyarakat, Rajawali Press, Jakarta, 1986.

Gerungan, WA. Psikologi Sosial, T. E'resco, Bandung, 1988.

Hendropuspito,SosiologiAgama, BPK. Gunung Mulia, Yogyakarta, 1991.

Hidayat Nataatmadja, Krisis Global Ilmu Pengetahuan dan Penyembuhannya, Iqra, Bandung, 1988.

Muhaimin, Problematika Agama dalam Kehidupan Manusia, Kalam Mulia, Jakarta, 1989.

Natsir,FiqhudDakwah, Ramadhani,Solo, 1989. Soerjono Soekamto, Pribadi dan Masyarakat, Alumni, Bandung, 1983.

Thomas F.O'dea, Sosiologi Agama, Rajawali Press, Jakarta, 1990. 